\title{
PAUL SCHRÖTER
}

\section{STENOGRAPHIEÜBUNGEN : FEUERBACHS}

KASPAR HAUSER (um 1930)

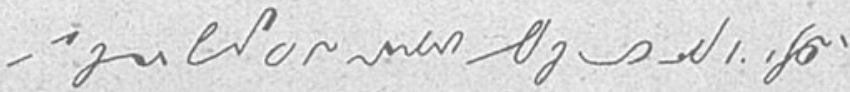

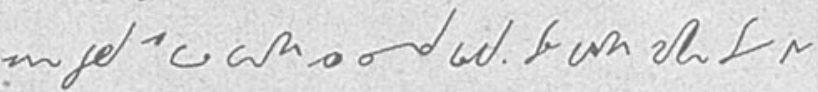

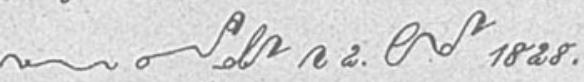

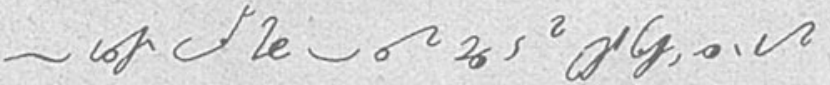

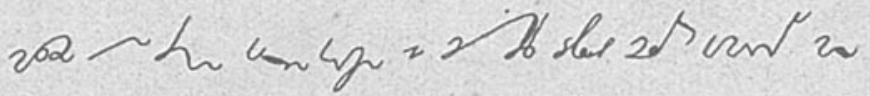

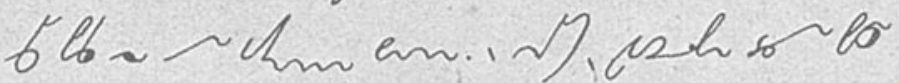

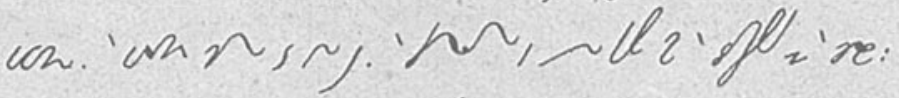

$$
\text { ancemple 4. ore v6.j.y }
$$

[Erevauleger] onts ands?

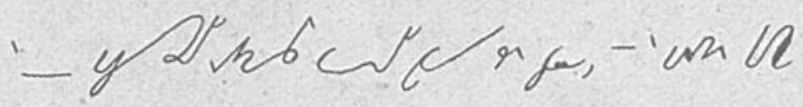

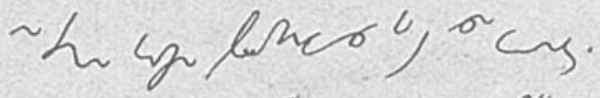

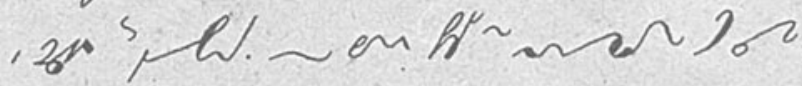

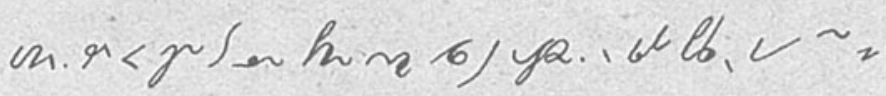

